\title{
Diagnosis of acquired generalized lipodystrophy in a single patient with T-cell lymphoma and no exposure to Metreleptin
}

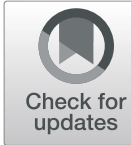

\author{
Nazanene H. Esfandiari ${ }^{1}$, Melvyn Rubenfire², Adam H. Neidert ${ }^{1}$, Rita Hench', Abdelwahab Jalal Eldin', \\ Rasimcan Meral ${ }^{1}$ and Elif A. Oral ${ }^{1 *}$ iD
}

\begin{abstract}
Background: Metreleptin, a recombinant methionyl -human -leptin, was approved to treat patients with generalized lipodystrophy (GL) in February 2014. However, leptin therapy has been associated with the development of lymphoma. We present a unique case of a patient with prior history of $\mathrm{T}$ cell lymphoma in remission, who was diagnosed with Acquired Generalized Lipodystrophy (AGL) during the following year after a clinical remission of her lymphoma without receiving leptin therapy.

Case presentation: A 33-year-old woman with a diagnosis of stage IV subcutaneous panniculitis like T-cell lymphoma in 2011, underwent chemotherapy. Shortly after completion therapy, she had a relapse and required more chemotherapy with complete response, followed by allogenic stem cell transplant on June 28, 2012. Since that time, she has been on observation with no evidence of disease recurrence. Subsequent to the treatment, she was found to have high triglycerides, loss of fat tissue from her entire body and diagnosis of diabetes. Constellation of these findings led to the diagnosis of AGL in 2013. Her leptin level was low at $3.4 \mathrm{ng} / \mathrm{mL}(182 \mathrm{pmol} / \mathrm{mL})$. She is currently not receiving any treatment with Metreleptin for her AGL.

Conclusions: Causal association between exogenous leptin therapy and T-cell lymphoma still remains unclear. We hereby present a case of a young woman who was diagnosed with AGL after going into remission from T-cell lymphoma and who has never been treated with Metreleptin. Steroid therapy and chemotherapy might have masked the diagnosis of AGL in this patient. We believe that patients can develop these 2 conditions independent of each other
\end{abstract}

Keywords: T-cell lymphoma, Acquired generalized lipodystrophy, Insulin resistance, Diabetes, Leptin

\section{Background}

Lipodystrophy is a rare disorder characterized by selective loss or absence of adipose tissue with leptin deficiency, ectopic lipid deposition, and severe metabolic abnormalities [1]. Lipodystrophy can be congenital or acquired and its distribution can be generalized or partial [2-4]. Metreleptin, a recombinant methionylhuman-leptin, was approved to treat generalized lipodystrophy in February 2014 [5]. Patients with acquired generalized lipodystrophy (AGL) present with loss of

\footnotetext{
* Correspondence: eliforal@med.umich.edu

${ }^{1}$ Division of Metabolism Endocrinology and Diabetes, Department of Internal Medicine, University of Michigan and Brehm Center for Diabetes, 1000 Wall Street, Room 5313, Ann Arbor, MI 48105, USA

Full list of author information is available at the end of the article
}

adipose tissue, hypertriglyceridemia, severe insulin resistance leading to diabetes and hepatic steatosis [3, 4]. Leptin therapy will improve many of the metabolic conditions in patients with AGL [6, 7]. Many patients with AGL have abnormal immune function and can even develop immunologic malignancies such as T-cell lymphoma [8].

Since a few patients with AGL developed T-cell lymphomas after being exposed to Metreleptin for some time, the FDA placed a black box warning to monitor for lymphomas and immune abnormalities while on Metreleptin even though a causal association between drug exposure and the development of the T-cell lymphoma was not established. In this report, we present a unique case of a patient with prior history of $\mathrm{T}$ cell lymphoma in remission, who was

(c) The Author(s). 2019 Open Access This article is distributed under the terms of the Creative Commons Attribution 4.0 International License (http://creativecommons.org/licenses/by/4.0/), which permits unrestricted use, distribution, and reproduction in any medium, provided you give appropriate credit to the original author(s) and the source, provide a link to the Creative Commons license, and indicate if changes were made. The Creative Commons Public Domain Dedication waiver (http://creativecommons.org/publicdomain/zero/1.0/) applies to the data made available in this article, unless otherwise stated. 
diagnosed with AGL during the following year after a clinical remission of her lymphoma. She has never received Metreleptin therapy. We believe that this report will add to the evidence that T-cell lymphoma and AGL may develop in the same patient independent of the use of Metreleptin or exogenous leptin therapy.

\section{Case presentation}

A 33-year-old woman without a significant past medical history, was diagnosed with stage IV subcutaneous panniculitis like T-cell lymphoma in 2011, complicated by hemophagocytic lymphohistiocytosis. She completed 6 cycles of CHOEP regimen (cyclophosphamide, doxorubicin, etoposide, vincristine and prednisone) in December 2011. Shortly after completion of the therapy, she relapsed and received multiple salvage regimens including gemcitabine/oxaliplatin, bexarotene/dexamethasone and pralatrexate. She was then initiated on ESHAP regimen; a combination of the chemotherapeutic drugs etoposide, methylprednisolone, a high-dose cytarabine and cisplatin in April 2012, achieving complete response; followed by an allogenic stem cell transplant on June 28, 2012. Since that time, she has been on observation with no evidence of disease recurrence. Subsequent to the treatment, she was found to have high triglycerides $(230 \mathrm{mg} / \mathrm{dL}$ [ $2.60 \mathrm{mmol} / \mathrm{L}$ ] (normal range $<150 \mathrm{mg} / \mathrm{dL}[1.69 \mathrm{mmol} / \mathrm{L}]$ ) in 2011 , and $613 \mathrm{mg} / \mathrm{dL}$ [6.93 mmol/L] in 2013) and loss of fat tissue from her entire body with accompanying muscular prominence. She was also diagnosed with diabetes in $12 / 2013$. Constellation of these findings led to the diagnosis of AGL in 2013.

At her visit in our clinic, her BMI was $24.4 \mathrm{~kg} / \mathrm{m}^{2}$. Her leptin level was low at $3.4 \mathrm{ng} / \mathrm{mL}(182 \mathrm{pmol} / \mathrm{mL}$ ) (a level of $<4 \mathrm{ng} / \mathrm{mL}[215 \mathrm{pmol} / \mathrm{mL}]$ is accepted as low for women with BMI $<25 \mathrm{~kg} / \mathrm{m}^{2}$ despite a wider range provided by some reference labs). Upon obtaining a detailed history, and reviewing her old pictures, it was confirmed that the onset of body fat loss occurred prior to her T-cell lymphoma diagnosis. She also endorsed complaints of hyperphagia and a marked increase in her appetite. Current clinical endocrine problems outside of diabetes and dyslipidemia include increased appetite and hyperphagia, lack of menses and a generalized pain syndrome likely attributable to small fiber neuropathy due to hypertriglyceridemia [9]. Table 1 summarizes her laboratory findings since the diagnosis until her last visit in our clinic. Figure 1 panels a-d show her pictures; before diagnosis (a), at diagnosis of T-cell lymphoma(b), during chemotherapy (c) and after chemotherapy (d).

At her most recent visit, she was doing well and is in remission for T cell Lymphoma. A "fat shadow" [10] representation from her DXA scan (panel a) and her new clinical pictures (panels b-e) are presented in Fig. 2. For her metabolic complications of her AGL, she is currently not being treated with Metreleptin and this possibility is still under discussion. She is on multiple medications to treat her diabetes, high triglycerides and has been trying to limit her food intake.

\section{Discussion and conclusions}

Several cases of T-cell lymphomas after Metreleptin exposure in patients with AGL have been described and led to a black box warning for the approval of Metreleptin in the United States. Over the past several years, there have been several case reports of AGL patients presenting with T-cell lymphomas who have never received leptin therapy. Given the rarity of the AGL, documentation of cases with T-cell lymphoma in the absence of Metreleptin therapy is

Table 1 Laboratory data from our case

\begin{tabular}{|c|c|c|c|c|c|}
\hline Year & $\begin{array}{l}\text { Glucose } \\
\mathrm{mg} / \mathrm{dL} \text { (mmol/L) }\end{array}$ & $\begin{array}{l}\mathrm{A} 1 \mathrm{C} \\
\%(\mathrm{mmol} / \mathrm{mol})\end{array}$ & $\begin{array}{l}\text { Triglycerides } \\
\mathrm{mg} / \mathrm{dL} \text { (mmol/L) }\end{array}$ & $\begin{array}{l}\text { Creatinine } \\
\mathrm{mg} / \mathrm{dL}(\mu \mathrm{mol} / \mathrm{L})\end{array}$ & $24-\mathrm{H}$ urine protein \\
\hline 2011 & $82(4.55)$ & & $230(2.60)$ & $0.4(35.4)$ & $0.61^{a}$ \\
\hline 2012 & $114(6.33)$ & & $416(4.70)$ & $0.8(70.7)$ & \\
\hline 2013 & $114(6.33)$ & $6.1(43)$ & $\begin{array}{l}466(5.27) \\
613(6.93)\end{array}$ & $1.1(97.2)$ & \\
\hline 2014 & 115 (6.38) & $6.4(46)$ & $\begin{array}{l}1027(11.6) \\
2577(29.1)\end{array}$ & $0.9(79.6)$ & $<5^{b}$ \\
\hline 2015 & $201(11.2)$ & $\begin{array}{l}5.9(41) \\
7.2(55)\end{array}$ & $\begin{array}{l}1372(15.5) \\
776(8.77)\end{array}$ & 1.05 (92.8) & $283^{b}$ \\
\hline 2016 & $201(11.2)$ & $\begin{array}{l}6.2(44) \\
6.9(52)\end{array}$ & $\begin{array}{l}478(5.40) \\
1392(15.7) \\
3615(40.9)\end{array}$ & $1.0(88.4)$ & \\
\hline 2017 & $146(8.10)$ & & $\begin{array}{l}1604(18.1) \\
740(8.36)\end{array}$ & $1.06(93.7)$ & \\
\hline 2018 & $103(5.72)$ & $7.7(61)$ & $\begin{array}{l}4380(49.5) \\
336(3.80)\end{array}$ & $1.05(92.8)$ & \\
\hline
\end{tabular}




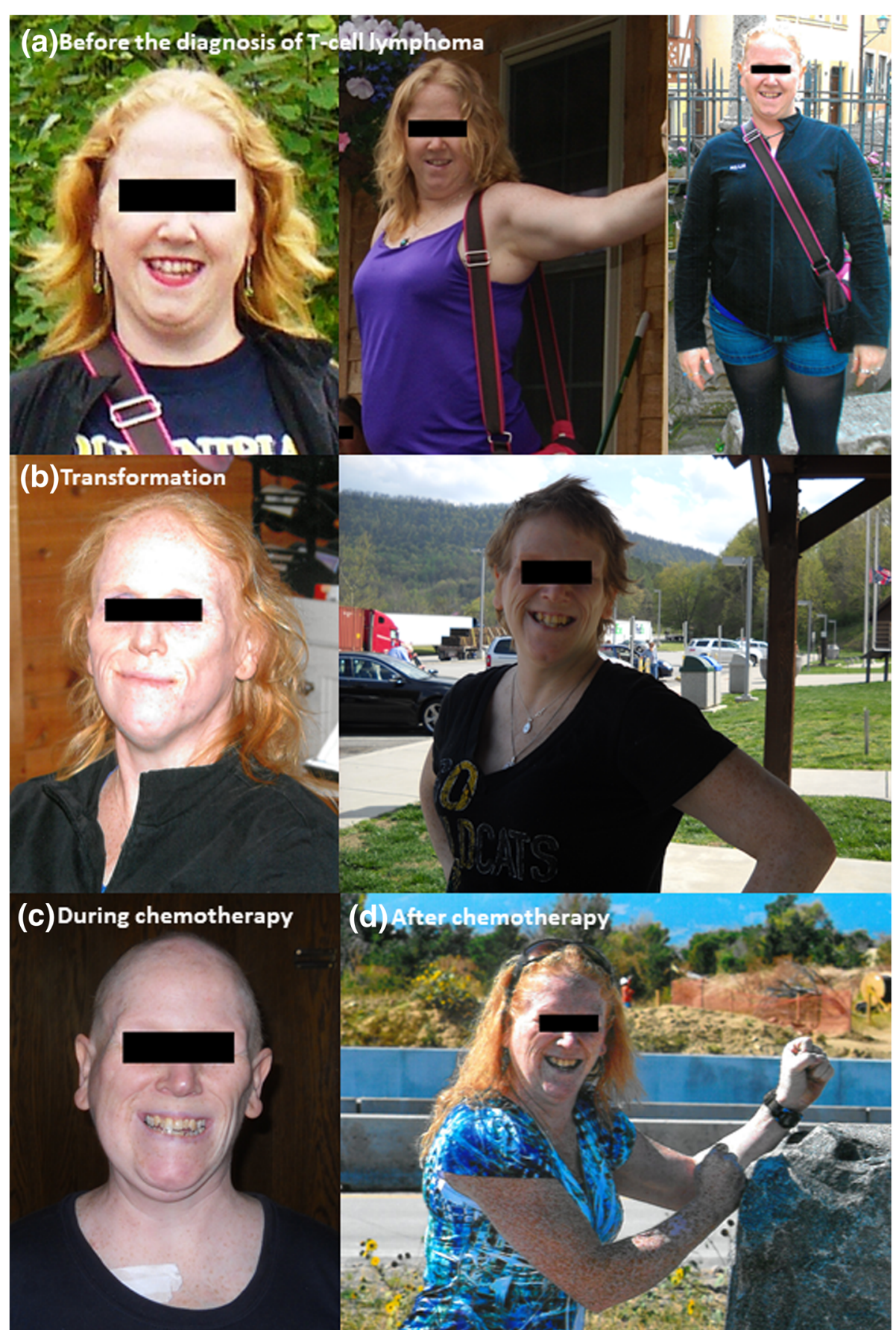

Fig. 1 Development of Physical Features of Lipodystrophy. Panel (a) shows the patient before the diagnosis of T-cell lymphoma and does not show convincing evidence for generalized lipodystrophy. Physical transformations are shown in panel (b) during the diagnosis of the T-cell lymphoma, suggesting that she may have already developed features of lipodystrophy at least around her face and neck. Panel (c) shows her appearance during chemotherapy and panel (d) is after the chemotherapy. Currently (4 years after the completion of therapy) patient's appearance is like the picture as shown in (b) suggesting that the chemotherapy and steroid use temporarily masked the diagnosis of lipodystrophy and were able to modify the physical appearance

quite important to provide the evidence base needed to provide assurance that Metreleptin is not playing a causal role in the development of the T-cell lymphomas. Our current report describes a unique case of a patient who developed adult onset AGL (which is quite rare), and who got diagnosed with the AGL after the remission of her T-cell lymphoma. It is important to underscore that this is distinctive than cases of children developing 


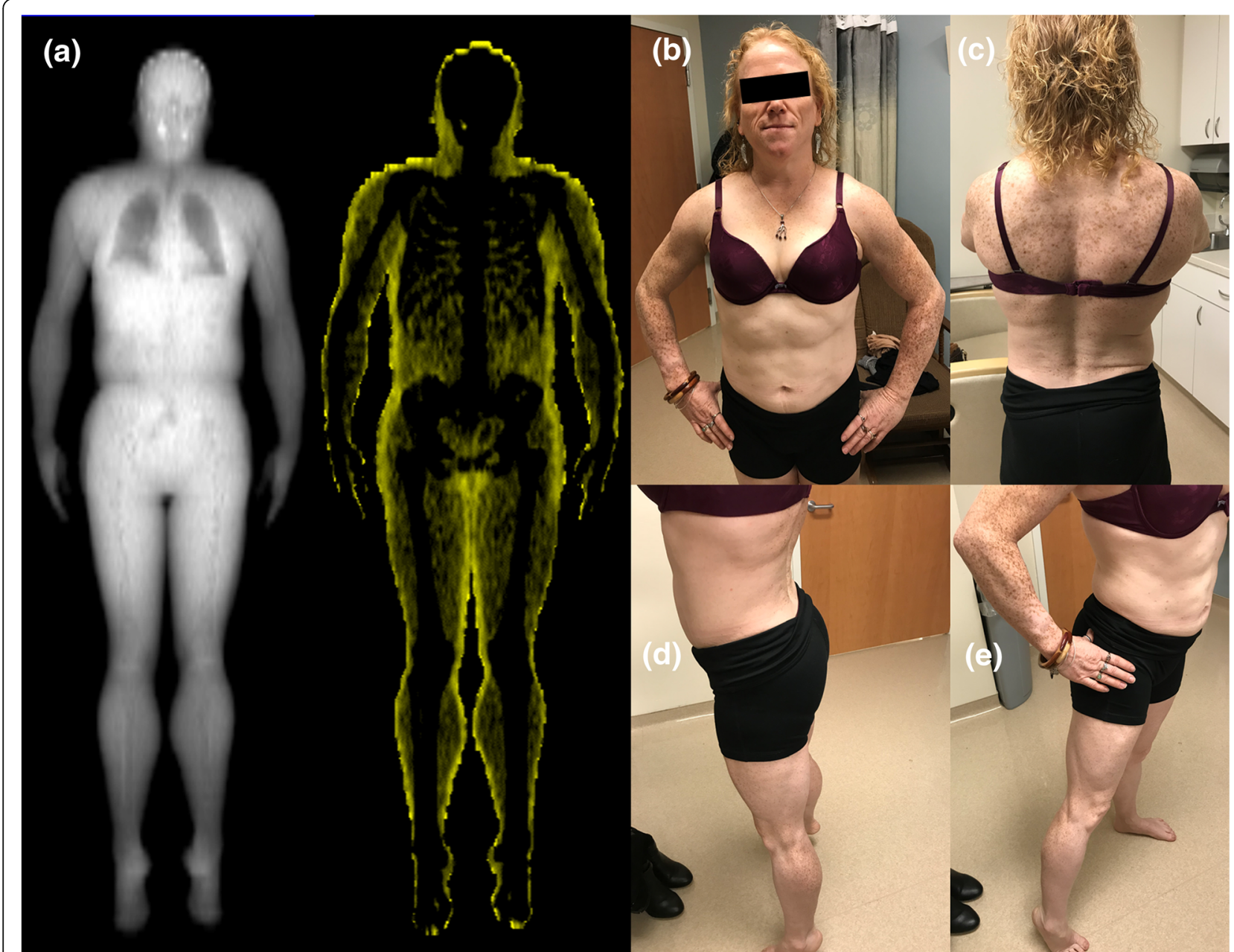

Fig. 2 Clinical Examination of Fat Distribution. Panel (a) show the "Fat Shadow" obtained from Dual X-ray Energy absorbtiometry (DXA) scan as described previously in Reference [10]. The fat shadow shows minimally retained fat around the neck and axilla, but loss of fat in a generalized fashion though not totally absent from the body. Close-up pictures taken in clinic setting demonstrate fat loss in the face and trunk (b), back (c), buttock and back of the legs (d), and forearms and legs (e). The absence of fat from the face together with the entire abdomen, trunk and extremities favor the diagnosis of generalized lipodystrophy as opposed to partial lipodystrophy. Neck fat is preserved, but not excessive. Mons pubis fat was not increased

partial lipodystrophy who have undergone hematopoietic stem cell transplantation during childhood [11].

Lymphomas, particularly peripheral T-cell lymphomas (PTCL), have been noted in AGL $[12,13]$. Brown et al. reported 5 cases of AGL and lymphoma [12]. The coexistence of AGL and lymphoma likely relates to an underlying autoimmune preponderance. Autoimmune diseases can occur commonly in patients with AGL $[8,12,14,15]$, including both organ-specific autoimmunity (e.g. type 1 diabetes, autoimmune hepatitis) and systemic autoimmune diseases (e.g. juvenile dermatomyositis) [12].

Lymphoma can be considered a systemic feature of AGL instead of an association with lipodystrophy per se given that other forms of lipodystrophy have not been associated with an increased risk of lymphomas [12]. Furthermore, it appears that patients with AGL are at an increased risk of the development of T-cell lymphomas, especially (PTCL), which is a heterogeneous and generally aggressive disorder. It is thought to be related to acquired lipodystrophy, as a subtype of PTCL localizes to the subcutaneous fat, termed subcutaneous panniculitis-like T-cell lymphoma. Panniculitis may be the presenting feature of AGL, as in the patient with AGL and PTCL reported by Yiannias and colleagues [16]. The clinical assessment of the potential role of Metreleptin in contributing to development and/or progression of lymphoma is limited by the lack of long term, controlled studies. Three out of 17 patients with AGL (18\%) developed T-cell lymphoma within the NIH cohort [5], an incidence significantly higher than what is observed in the general population (approximately 2 per 100,000) [17]. 
Another interesting case of PTCL subsequently complicated by AGL has been described by Aslam et al. [18]. Misra and Garg proposed three classification types for AGL based on the etiology and pathological mechanisms: type 1 represents AGL associated with panniculitis; type 2 represents AGL with accompanying autoimmune diseases, and type 3 represents idiopathic AGL [8]. Aslam et al. felt that their patient developed AGL and likely represented an overlap of both the type 2 and 3 varieties [18]. The classification of AGL is likely not to be as simple, and there are newer case reports that may change or challenge these earlier classifications.

The time course of the development of AGL was interesting in our case. One possibility is that our patient started to develop AGL while she was going through the diagnosis of her $\mathrm{T}$ cell lymphoma as she had panniculitis related T-cell lymphoma. Her treatment with chemotherapy and steroids may have been a contributing factor in her clinical presentation. Steroids might have also masked the features of AGL until the remission of T cell lymphoma and discontinuation of steroids.

In conclusion, there are several clinical lessons from our case. First, development of extensive panniculitis in an adult patient who is losing body fat should raise suspicion of for both T-cell lymphoma and AGL. These patients should be vigilantly monitored for the development of metabolic complications over time. Finally, the association of T-cell lymphoma with known panniculitis within the setting of AGL may be expected and is not likely impacted by Metreleptin therapy.

\section{Abbreviations}

AGL: Acquired generalized lipodystrophy; GL: Generalized lipodystrophy; PTCL: Peripheral T-cell lymphoma

\section{Acknowledgments}

The authors thank the patient for letting us to report her unique case and sharing her pictures.

\section{Funding}

Dr. Oral was partially supported by R01 DK088114. The work was supported by generous gifts to the Lipodystrophy Fund at the University of Michigan made by the Sopha family, lonis Pharmaceuticals and the White Point Foundation of Turkey. These funding sources had no interference in the study design or direction.

Dr. Oral also received grant support from and served as an advisor to Amylin Pharmaceuticals LLC, Bristol-Myers-Squibb, AstraZeneca in the past. She is currently receiving grant support from Gemphire Therapeutics, Aegerion Pharmaceuticals, lonis Pharmaceuticals and Akcea Therapeutics and serving as an advisor to Aegerion Pharmaceuticals, Akcea Therapeutics and Regeneron Pharmaceuticals. Dr. Oral recently completed grant support from Gl Dynamics.

Availability of data and materials

The datasets analyzed during this study are included in this published article.

\section{Authors' contributions}

NHE gathered the data and wrote the manuscript. MR evaluated the patient in lipid clinic, reviewed and edited the manuscript. AHN, AJE and RH provided help in contacting the patient to get her pictures and obtained the written consent form, reviewed and edited the manuscript. RM helped in making her pictures appropriate for this manuscript, reviewed and edited the manuscript. EAO evaluated the patient, confirmed the diagnosis of lipodystrophy (currently follows the patient), reviewed and edited the manuscript. All authors read and approved the final manuscript.

\section{Ethics approval and consent to participate}

There is no Ethics approval and consent to participate as this is a single case report.

\section{Consent for publication}

Patient has given us written consent for publication.

\section{Competing interests}

The authors declare that they have no competing interests.

\section{Publisher's Note}

Springer Nature remains neutral with regard to jurisdictional claims in published maps and institutional affiliations.

\section{Author details}

${ }^{1}$ Division of Metabolism Endocrinology and Diabetes, Department of Internal Medicine, University of Michigan and Brehm Center for Diabetes, 1000 Wall Street, Room 5313, Ann Arbor, Ml 48105, USA. ${ }^{2}$ Division of Cardiovascular Medicine, Department of Internal Medicine, University of Michigan, Ann Arbor, MI, USA.

Received: 20 August 2018 Accepted: 29 January 2019

Published online: 14 March 2019

\section{References}

1. Chan JL, Lutz K, Cochran E, Huang W, Peters Y, Weyer C, et al. Clinical effects of long-term metreleptin treatment in patients with lipodystrophy. Endocr Pract. 2011;17(6):922-32.

2. Handelsman Y, Oral EA, Bloomgarden ZT, Brown RJ, Chan JL, Einhorn D, et al. The clinical approach to the detection of lipodystrophy - an AACE consensus statement. Endocr Pract. 2013;19(1):107-16.

3. Chan JL, Oral EA. Clinical classification and treatment of congenital and acquired lipodystrophy. Endocr Pract. 2010;16(2):310-23.

4. Garg A. Clinical review\#: lipodystrophies: genetic and acquired body fat disorders. J Clin Endocrinol Metab. 2011;96(11):3313-25.

5. Golden J. The Endocrinologic and Metabolic Drugs Advisory Committee Meeting Briefing Document BLA 125390 Myalept (metreleptin for injection) FDA.gov archive-it.org: Food and Drug Administration Center for Drug Evaluation and Research; 2013 [Available from: https:// wayback.archive-it.org/7993/20170405215819/https://www.fda.gov/ downloads/AdvisoryCommittees/CommitteesMeetingMaterials/Drugs/ EndocrinologicandMetabolicDrugsAdvisoryCommittee/UCM377928.pdf.

6. Oral EA, Simha V, Ruiz E, Andewelt A, Premkumar A, Snell P, et al. Leptinreplacement therapy for lipodystrophy. N Engl J Med. 2002;346(8):570-8.

7. Rodriguez AJ, Mastronardi CA, Paz-Filho GJ. New advances in the treatment of generalized lipodystrophy: role of metreleptin. Ther Clin Risk Manag. 2015:11:1391-400

8. Misra A, Garg A. Clinical features and metabolic derangements in acquired generalized lipodystrophy: case reports and review of the literature. Medicine (Baltimore). 2003;82(2):129-46.

9. Wiggin TD, Sullivan KA, Pop-Busui R, Amato A, Sima AA, Feldman EL. Elevated triglycerides correlate with progression of diabetic neuropathy. Diabetes. 2009;58(7):1634-40

10. Meral R, Ryan BJ, Malandrino N, Jalal A, Neidert AH, Muniyappa R, et al. "fat shadows" from DXA for the qualitative assessment of lipodystrophy: when a picture is worth a thousand numbers. Diabetes Care. 2018;41(10):2255-8.

11. Adachi M, Oto Y, Muroya K, Hanakawa J, Asakura Y, Goto H. Partial lipodystrophy in patients who have undergone hematopoietic stem cell transplantation during childhood: an institutional cross-sectional survey. Clin Pediatr Endocrinol. 2017;26(2):99-108.

12. Brown RJ, Chan JL, Jaffe ES, Cochran E, DePaoli AM, Gautier JF, et al. Lymphoma in acquired generalized lipodystrophy. Leuk Lymphoma. 2016; 57(1):45-50.

13. Brown RJ, Araujo-Vilar D, Cheung PT, Dunger D, Garg A, Jack M, et al. The diagnosis and Management of Lipodystrophy Syndromes: a multi-society practice guideline. J Clin Endocrinol Metab. 2016;101(12):4500-11. 
14. Savage DB, Semple RK, Clatworthy MR, Lyons PA, Morgan BP, Cochran EK, et al. Complement abnormalities in acquired lipodystrophy revisited. J Clin Endocrinol Metab. 2009;94(1):10-6.

15. Garg A. Acquired and inherited lipodystrophies. N Engl J Med. 2004; 350(12):1220-34.

16. Yiannias JA, DiCaudo DJ, Maskin E. Peripheral T-cell lymphoma presenting as lipoatrophy and nodules. Int I Dermatol. 2006;45(12):1415-9.

17. Wang SS, Vose JM. Epidemiology and prognosis of T-cell lymphoma. In: Foss F, editor. T-cell lymphomas. Totowa, NJ: Humana Press; 2013. p. 25-39.

18. Aslam A, Savage DB, Coulson $\mathbb{H}$. Acquired generalized lipodystrophy associated with peripheral T cell lymphoma with cutaneous infiltration. Int J Dermatol. 2015;54(7):827-9.

Ready to submit your research? Choose BMC and benefit from:

- fast, convenient online submission

- thorough peer review by experienced researchers in your field

- rapid publication on acceptance

- support for research data, including large and complex data types

- gold Open Access which fosters wider collaboration and increased citations

- maximum visibility for your research: over $100 \mathrm{M}$ website views per year

At BMC, research is always in progress.

Learn more biomedcentral.com/submissions 